\title{
The Heart of Power
}

Health and Politics in the Oval Office

\author{
David Blumenthal and \\ James A. Morone
}

With a New Preface

甲

UNIVERSITY OF CALIFORNIA PRESS

Berkeley . Los Angeles · London 
University of California Press, one of the most distinguished university presses in the United States, enriches lives around the world by advancing scholarship in the humanities, social sciences, and natural sciences. Its activities are supported by the UC Press Foundation and by philanthropic contributions from individuals and institutions. For more information, visit www.ucpress.edu.

University of California Press

Berkeley and Los Angeles, California

University of California Press, Ltd.

London, England

(C) 2009, 20I0 by The Regents of the University of California

ISBN 978-0-520-26809-8

The Library of Congress has cataloged an earlier edition as follows:

Blumenthal, David, I948-

The heart of power : health and politics in the Oval Office / David Blumenthal and James A. Morone.

p. ; cm.

Includes bibliographical references and index.

ISBN 978-0-520-26030-6 (cloth: alk. paper)

I. Medical policy-United States-History.

2. Presidents-United States-Health. I. Morone, James A., I95 I- II. Title.

[DNLM: I. Health Policy-history-

United States. 2. Federal Governmenthistory-United States. 3. History, 2oth Century-United States. 4. History, 2 Ist CenturyUnited States. 5. Leadership--United States.

6. Policy Making-United States. 7. Politics-United States. 8. Public Health Practice-history-United States. WA 540 AAI B648h 2009]

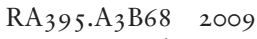

362.10973-dc22

2008054361

Manufactured in the United States of America

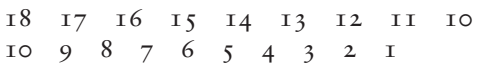

The paper used in this publication meets the minimum requirements of ANSI/NISO Z 39.48-I992 (R I997) (Permanence of Paper). 